\title{
Assessment of Educational Neuromyths among Teachers and Teacher Candidates
}

\author{
Tuncay CANBULAT ${ }^{1} \&$ Halit KIRIKTAS ${ }^{2}$ \\ ${ }^{1}$ Department of Classroom Teaching, University of Dokuz Eylül, İzmir, Turkey \\ ${ }^{2}$ Department of Science Education, University of Dokuz Eylül, İzmir, Turkey \\ Correspondence: Halit KIRIKTAS, Department of Classroom Teaching, University of Dokuz Eylül, İzmir, \\ Turkey. E-mail: halit.kiriktas@gmail.com
}

Received: March 16, 2017

Accepted: March 25, $2017 \quad$ Online Published: April 4, 2017

doi:10.5539/jel.v6n2p326

URL: http://doi.org/10.5539/jel.v6n2p326

\begin{abstract}
The aim of study is to determine the neuromyth level of teachers and pre-teachers and reveal if there is significant difference in terms of some variables (gender, class, etc.). Research was designed in survey model. The research sample was formed with 241 teachers and 511 teacher candidates. In the collection of data, "Educational neuromyhts test" that has 31 questions with options "right, wrong, I have no idea" that was created by the authors by applying reliability studies. Score that can be taken from measuring tool are in the range of $0-31$. According to the findings; while teachers are having an average score of " 18,87 ", teacher candidates received an average score of " 16,70 ". According to this result, teacher and teacher candidates have misplaced half of the questions of neurometry. While comparing the scores of teachers and teacher candidates, a significant difference in favor of the teachers $(\mathrm{p}=.000)$ were found. The results of the research are expected to led to a debate on "brain and learning" issues.
\end{abstract}

Keywords: neuromyth, brain-based learning, teacher candidate, Turkey

\section{Introduction}

As brain is the organ where learning takes place, the structure and functioning of brain have always been the educators' centre of attention. The rapid growth of neuro-imaging technologies provide significant clues for both the medical world and the educators. Despite the fact that there are numerous unknowns on what rate the information acquired affects the brain functions and how the educators can use these information, it is not possible to ignore all these data completely. Thanks to the technologies developed, significant contribution has been made to the exploration of structural and functional characteristics of the brain; and due to the use of neuro-psychological tests, significant data resulting with changes in the educational field, have been reached (Dwyer, 2002; Gülpınar, 2005). As a result of these researches concerning brain and learning, a learning and teaching approach called as "Brain-Compatible Learning, Brain-Dependent Learning, Neuro-Physiological Learning or Brain-Based Learning", has been put forward in the literature (Caine R. \& Caine G., 1991; Sylwester, 1995; Diamond \& Hopson, 1998; Jensen, 1998; Wolfe, 2001; Sousa, 2001; Duman, 2007; Canbulat, 2016). However, according to several research findings, many techniques used under the name of brain-dependent learning, are neuromyth; that is the findings in neuroscience have been misunderstood and misused (Bruer, 1998; Goswami, 2004; Blakemore \& Frith, 2005; Goswami, 2006; OECD, 2002; Dekker et al., 2012; Canbulat \& Doğan Altun, 2013; Howard-Jones, 2014; Gleichgerrcht, Luttges, Salvarezza, \& Campos, 2015).

\section{Literature Review}

The project called as "Brain and Learning" which belongs to OECD 2000 [Organization for Economic Co-operation, and Development] that first drew attention to the subject of neuromyth, attracted attention to this phenomenon internationally. Especially, it was indicated that the gap between neuroscience and education cause many misunderstandings (Goswami, 2006).

As it was stated that only $10 \%$ of the brain is used; the examples such as multiple intelligence, difference in the learning style and learners according to the dominance of the right and left hemisphere of the brain, were determined as frequently encountered neuromyths (OECD, 2002). Several misunderstandings as such, have set 
ground for popular educational programs such as mind exercise and VAK (Visual, Auditory and Kinaesthetic Learners) approach. There is a common interest in the use of neuroscience findings among the teachers. This interest has both led to the use of neuromyth in the learning environments and to the increase in the number of the researches carried out on this subject. In their study, Dekker et al. (2012) reached the conclusion that; 242 teachers working in United Kingdom and Netherlands believed in the half of neuromyth given, particularly $98 \%$ of the teachers believed in learning styles, $82 \%$ believed in mind exercise, and $71 \%$ believed in multiple intelligence theories.

Rato, Castro-Caldas and Abreu (2013), Based on a sample of 583 Portuguese teachers from different areas of expertise participated in this study. Their results suggest that teachers fail to distinguish myths from facts, irrespective of the area taught and level of teaching. However, our findings also indicate that, although teachers have difficulties in untangling myths from facts, Portuguese teachers are interested in the workings of the brain and recognise the potential of neuroscientific information in education.

Howard-Jones (2014) reached the conclusion that there is a great belief in the neuromyths among the English, German, Turkish, Greek and Chinese primary and secondary school teachers. Howard-Jones found that teachers were quite susceptible to neuromyths, including the idea that humans only use 10 percent of their brains and that children are less attentive after consuming sugary snacks.

Karakus, Howard-Jones and Jay (2014) analyses revealed that teachers held many misconceptions about concepts related to brain that have been observed elsewhere in Europe. On the other hand the comparison between Turkey, UK and Netherlands revealed some interesting differences. For instance the conceptions about the neuromyths on second language learning and plasticity were differentiated between countries. This could show the differences between cultures. There is a need to do distinctive scientific research in Turkey as well.

Gleichgerrcht et al. (2015) made research on 3451 teachers from Latin American countries. In their research, they asked about the general information on the brain and questions involving the neuromyth claims. Half of the teachers answered 2 out of 3 claims correctly regarding the general information on the brain. Half of the teachers failed to distinguish 9 out of 12 invalid information on the neuromyth claims. Furthermore, it was concluded that teachers who have much more knowledge on the brain, are more prone to believe in the invalid claims in the brain research and applications.

The results obtained in Ferrero, Garaizar and Vadillo (2016) showed that Spanish teachers believed a considerable number of the neuromyths. Specifically, from a total of 12 neuromyths presented, five were believed by more than $50 \%$ of the educators.

The objective of this research, is to determine the neuromyth levels of teachers and teacher candidates, and to present whether there is a significant difference among them in terms of several variables (gender, class, seniority etc.)

\section{Sub-Problems of the Research Are Determined as Below}

a) Are there significant differences among the "Educational Neuromyth Test" scores of the Teachers and Teacher Candidates?

b) Are there significant differences among the "Educational Neuromyth Test" scores of the teachers in accordance with their

$>$ Gender
$>$ Seminar participation status
$>$ Experiences
$>$ Branches

c) Are there significant differences among the "Educational Neuromyth Test" scores of the teacher candidates' in accordance with their

$>$ Gender

$>$ Seminar participation status

$>$ Experiences

$>$ Branches 


\section{Methodology}

The study was designed in the research screening model. This is a descriptive study carried out in order to determine the neuromyth levels among the Class Teachers-class teacher candidates and Science Teachers-science teacher candidates. "Screening model; is a research design aiming to describe a situation that belongs to past or present in its true form" (Karasar, 2013, p. 77).

\subsection{Participants}

The research sample; consisted of total 752 people; 241 teachers working in 2015-2016 academic year in Izmir province of Turkey, and 511 teacher candidates receiving education in Buca Faculty of Education of Dokuz Eylül University.

\subsection{Data Collection Tools}

In Data Collection, OECD 2002 and OECD 2007, Tokuhama-Espinosa (2008) and Dekker et al. (2012) studies were used, expert opinions were received, and "educational neuromyths" test of 31 articles (correct, wrong and no-idea) created by the authors, was also used. As a result of the reliability analysis of the test, Cronbach's Alpha reliability coefficient of the test was calculated as 0,675 . It can be understood that the assessment tool created as indicated in the literature, is a reliable assessment tool (Haladyna \& Rodriguez, 2013). The score interval of the assessment tool is between 0-31. It can be said that, as the score rises, the awareness level on the subject also rises.

\subsection{Data Analysis}

The research data were analyzed in SPSS 21 package program. Descriptive statistics, reliability analysis and non-parametric analyses were used on the data. In the analyses carried out via the data acquired from the sample consisting of 752 people, the statistical limit of significance was taken as (p) .05.

\section{Findings}

In this section of the research, findings and comments on the findings reached after the evaluation of the data collected via scales, are given. The order of sub-problems is followed in the presentation of the findings.

Table 1. Average statistics of teacher and teacher candidates' "educational neuromyth test"

\begin{tabular}{lccc}
\hline Groups & N & \multicolumn{2}{c}{ Scores } \\
\hline & & $\bar{X}$ & Ss \\
\hline Teacher Candidate & 511 & 16,70 & 3.62 \\
Teacher & 241 & 18,87 & 4.20 \\
Total & 752 & 17,40 & 3.96 \\
\hline
\end{tabular}

When the findings acquired from the analyses were evaluated, it was concluded that; while teachers achieved " 18,87 " point average in educational neuromyth test, teacher candidates achieved " 16,70 " point average in the same test. When considered that the highest possible score is 31 , teachers and teacher candidates answered almost $50 \%$ of the questions wrongly.

In frequently encountered neuromyths, teachers' and teacher candidates' belief of only $10 \%$ of the brain is used, was determined as $75 \%$, their belief of learning styles as $20 \%$, and the dominance of the right and left hemispheres of the brain, was determined as $97 \%$. The results of Mann Whitney U Test carried out in order to determine whether the score difference among the groups is significant or not, are given in Table 2. 
Table 2. The results of Mann Whitney U Test regarding the "educational neuromyth test" scores of teachers and teacher candidates

\begin{tabular}{llccccc}
\hline Variables & Groups & N & Order Average & Order Total & U & P \\
\hline \multirow{2}{*}{ Employment Status } & Teacher & 241 & 476,46 & 114826 & \multirow{2}{*}{37485} & .00 \\
& Teacher Candidate & 511 & 329,36 & 168301 & & \\
\hline
\end{tabular}

When the scores got by teachers and teacher candidates from the educational neuromyth test, it can be seen that there is a significant difference $(p<.05)$ in favor of teachers. This outcome shows that teachers' awareness on the subject of "brain and learning", is higher than the teacher candidates.

Findings regarding the sub-problems such as; Are there significant differences among the teachers' educational neuromyth scores according to their gender and seminar/course status on the subject of "brain and learning" are given in Table 3.

Table 3. The results of Mann Whitney U Test regarding the teachers' "educational neuromyth test" scores according to their gender and seminar/course status

\begin{tabular}{lcccccc}
\hline Variables & Groups & N & Order Average & Order Total & U & P \\
\hline Gender & Female & 160 & 125,98 & 20157 & 5683 & .11 \\
& Male & 81 & 111,16 & 9004 & & \\
\multirow{2}{*}{ Seminar Status } & Yes & 68 & 139,24 & 9468 & 4641 & .01 \\
& No & 173 & 113,83 & 19692 & & \\
\hline
\end{tabular}

When Table 3 is analyzed, it can be seen that there is not a significant difference among the teachers' educational neuromyth differences when the participant female and male teachers' scores are compared to each other ( $U=5683 ; p>.05)$. In accordance with this outcome, it can be said that female or male teachers' knowledge on the subject, is similar.

A significant difference was found in favor of the people taking seminar/course, when the teachers' scores were compared on the subject of brain and learning according to their seminar/course status $(\mathrm{U}=4641 ; \mathrm{p}<.05)$. According to this finding, it can be said that seminar/course status is a significant determiner in increasing the educational neuromyth awareness.

Findings regarding the sub-problems such as: "Are there significant differences among the teachers' educational neuromyth scores according to their branches and years of experience?" are given in Table 4.

Table 4. The results of Kruskal Wallis Test regarding the teachers' "educational neuromyth scores" according to their branches and years of experience

\begin{tabular}{lllllll}
\hline Variables & Groups & N & Order Average & sd & $\mathbf{X}^{\mathbf{2}}$ & $\mathbf{p}$ \\
\hline \multirow{2}{*}{ Experience } & Between 1-5 years & 36 & 142,24 & & & \\
& Between 6-10 years & 45 & 127,12 & & & \\
& Between 11-15 years & 47 & 101,77 & 4 & 9,209 & $\mathbf{. 0 5 6}$ \\
& Between 16-20 years & 43 & 108,44 & & \\
\hline \multirow{2}{*}{ Branch } & Between 21 years and over & 70 & 126,77 & & & \\
& Class Teacher & 76 & 111,45 & & & \\
& Middle School Teacher & 117 & 121,53 & & & \\
& High School Teacher & 48 & 134,83 & & & \\
\hline
\end{tabular}


When Table 4 is analyzed, it can be seen that there is not a significant difference among the teachers' educational neuromyth scores when they are compared according to their experiences $\left(X^{2}=9,209 ; p>05\right)$.

When the teachers' scores are compared according to their branches, it can be seen that there is not a significant difference among their educational neuromyth differences $\left(X^{2}=3,346 ; p>.05\right)$.

According to this outcome, it can be said that the teachers' differences on the subject of brain and learning according to their experiences and branches, are similar.

Findings regarding the sub-problems such as: Are there significant differences among the Teachers' Educational Neuromyth Scores according to their gender and seminar/course status on the subject of "brain and learning" are given in Table 5 .

Table 5. The results of Mann Whitney U Test regarding the teachers' "educational neuromyth test" according to their genders and seminar/course status on the subject of "brain and learning"

\begin{tabular}{lllllll}
\hline Variables & Groups & N & Order Average & Order Total & U & p \\
\hline Gender & Female & 398 & 261,73 & 104168 & 20206 & .09 \\
& Male & 113 & 235,82 & 26647 & & \\
Seminar & Yes & 68 & 306,25 & 20825 & 11645 & .00 \\
Status & No & 443 & 248,29 & 109991 & & \\
\hline
\end{tabular}

When Table 5 is analyzed; it can be seen that there is a significant difference among the educational neuromyth awareness in favor of the female teacher candidates when the teacher candidates' scores are compared according to their gender $(\mathrm{U}=20206 ; \mathrm{p}<.05)$. According to this finding, female teacher candidates' educational neuromyth awareness is at a better level than the male teacher candidates.

When teacher candidates' scores were compared according to their seminar/course status on the subject of brain and learning, a significant difference was found in favor of the people taking seminars/courses $(U=11645 ; p<.05)$. According to this finding, it can be said that seminar/course status is a significant determiner when the scores are compared.

Table 6. The results of Kruskal Wallis Test regarding the teacher candidates' "educational neuromyth test" scores according to their academic standing and classes

\begin{tabular}{ccccccc}
\hline Variables & Groups & n & Order Average & sd & $\mathbf{X}^{\mathbf{2}}$ & $\mathbf{p}$ \\
\hline \multirow{3}{*}{ Academic Standing } & $\mathbf{0 . 0 0 - 2 . 0 0}$ & 103 & 222,67 & & & \\
& $\mathbf{2 . 0 1 - 3 . 0 0}$ & 314 & 261,64 & 2 & 7,108 & $\mathbf{. 0 2}$ \\
& $\mathbf{3 . 0 1 - 4 . 0 0}$ & 94 & 273,68 & & & \\
\hline \multirow{2}{*}{ Class Level } & 1st Class & 122 & 254,59 & & & \\
& 2nd Class & 118 & 232,19 & 3 & 5,335 & $\mathbf{. 0 2}$ \\
& 3rd Class & 144 & 274,11 & & & \\
& 4th Class & 127 & 258,93 & & & \\
\hline
\end{tabular}

When Table 6 is analyzed; a significant difference was found in the teacher candidates' educational neuromyth awareness when their scores were compared according to their academic standing $\left(X^{2}=7,108 ; p<.02\right)$. As a result of Mann-Whitney U Test carried out in order to determine among which groups the differences were; it was understood that the educational awareness of teacher candidates whose academic grade point average were between 2.01-3.00 and 3.01-4.00, was at a better level than the teacher candidates whose academic success was between $0.00-2.00$. According to this finding, it can be said that successful teacher candidates' educational neuromyth awareness was high.

A significant difference was found among the teacher candidates' educational neuromyth awareness when their scores were compared according to their class level $\left(\mathrm{X}^{2}=5,335 ; \mathrm{p}<.02\right)$. As a result of Mann-Whitney $\mathrm{U}$ test 
carried out in order to determine among which groups the differences were; it can be said that the teacher candidates', who are continuing their education in 3rd grade, awareness on brain and learning was at a better level than the teacher candidates continuing their education in 2 nd grade.

\section{Discussion and Conclusion}

In this research, the educational neuromyth awareness of a group of teachers and teacher candidates, was evaluated. According to the findings acquired from the research; it can be seen that teachers and teacher candidates answered almost $50 \%$ of the questions wrongly when considered that the highest possible score in the educational neuromyth test is 31 . However, it was concluded that the teachers' awareness on the subject of brain and learning was significantly higher than the teacher candidates. It was found out that the educational awareness of teachers and teacher candidates who were indicated to have taken seminar/course on the subject of brain and learning, was at a better level than the teachers and teacher candidates who didn't take seminar/course.

The educational neuromyth awareness of teachers whose academic point average is between 2.01-3.00 and 3.01-4.00, is at a better level than the teacher candidates whose academic point average is between $0.00-2.00$. The educational neuromyth awareness of teacher candidates', who are continuing their education in 3rd grade, is at a better level than the teacher candidates continuing their education in 2 nd grade. In general, these results are similar to the study, where the teachers believe in more than $50 \%$ of the neuromyths, carried out by Dekker et al. (2012) on English and Dutch teachers, due to 70\% correct answer rate in the field of brain knowledge. In addition, the use of only $10 \%$ of the brain by Rato, Castro-Caldas and Abreu (2013), Howard-Jones (2014), Karakus, Howard-Jones and Jay (2014), Ferrero, Garaizar and Vadillo (2016), is also similar to the results of the neuromyth samples such as multiple intelligence, learning style differences, and learners according to the dominance of right and left hemispheres of the brain. In the study they carried out on the English teachers working in USA and Canada, Lethaby and Harries (2016) reported the conclusion that while neuromyths are decreased, they also continue to exist. Particularly, there is a lower rate than the research results above regarding the learning styles. However, in the studies carried out on the subject, it can be seen that the neuromyths will continue to exist.

As neuromyths present reasonable explanations to the people and because they approach to the daily matters with friendly statements, it is clear that they have started to appeal to the public (Howard-Jones, 2014). In many cases, these neuromyths are the outcomes of translation mistakes or sufficient translation attempts (Daniel, 2012). Therefore, the need for acceptable translation and for the original article not losing its meaning, has come to the forefront (Gleichgerrcht et al., 2015). When it is considered that the deceptive use of science will have a cost in education, it is concluded that it is essential not to ignore the researches carried out on the subject. For instance, managements and schools might be investing money and time in fake science-based programs. This might eventually end up with outcomes such as teachers turning their back on the potential effects of neuroscience on education. It is reassuring and inspiring that teachers are still open to new information and education after these much hard and tiresome studies. In a way, this might lead to an unfavorable outcome, because this enthusiasm in ne information might cause the teachers to be inclined to encounter fake science at the same time. At this point, it is the relevant stakeholders' duty to provide reliable information for the teachers and to make correct translation (Pasquinelli, 2012; Gleichgerrcht et al., 2015).

\section{Suggestions}

Suggestions developed in accordance with the research results, are given above:

$>$ It is essential to give necessary training to the teachers and teacher candidates on mind and brain applications.

$>$ It is essential to give in-service courses to the teachers in the years to come, and updated and correct information should be provided for them.

$>$ It is essential to provide pre-service information for the teacher candidates on neuroscience by means of elective or compulsory courses, or by making additions to special education lessons.

$>$ It is essential to arouse the male teacher candidates' interest on the subject.

It is essential to give practical and solid sample-based training to the teachers on neuroscience.

It is considered that the results of this research might create a thinking and discussion environment based on several problems encountered in neuroscience and neuromyth; and that it might also raise awareness on the relevant subject by contributing to the inter-country comparisons. 


\section{References}

Blakemore, S. J., \& Frith, U. (2005). The learning brain: Lessons for education, A précis. Developmental Science, 8(6), 459-465. https://doi.org/10.1111/j.1467-7687.2005.00434.x

Bruer, J. T. (1998). Brain Science, Brain Fiction. Educational Leadeship, 56(3), 14-18.

Caine, R. N., \& Caine, G. (1991). Making connections: Teaching and the human brain. New York: Addison-Wesley Publishing Company.

Canbulat, T. (2016). The effect of the brain compatible learning approach on fifth grade students' executive functions in social sciences course. International Journal of Active Learning (IJAL), 1(1), 29-48.

Canbulat, T., \& Doğan-Altun, Z. (2013). Yeni bir ögrrenme-öğretme yaklaşımı "Zihin, Beyin ve Eğitim'e (Nöroeğitim)" İlişkin Genel Bir Değerlendirme. XII. Ulusal Sınıf Öğretmenliği Eğitimi Sempozyumu, Aydın, Turkey.

Daniel, D. B. (2012). Promising principles: Translating the science of learning to educational practice. Journal of Applied Research in Memory and Cognition, 1, 251-253. https://doi.org/10.1016/j.jarmac.2012.10.004

Dekker, S., Lee, N. C., Howard-Jones, P., \& Jolles, J. (2012). Neuromyths in education: Prevalence and predictors of misconceptions among teachers. Frontiers in Psychology, 3, 429. https://doi.org/10.3389/fpsyg.2012.00429

Diamond, M., \& Hopsan, J. (1998). Magic trees of the mind. New York: Dutton Books, Penguin-Putnam Group.

Duman, B. (2007). Neden beyin temelli ögrrenme? Ankara: Pegem A Yayınc1lık.

Dwyer, B. M. (2002). Training Strategies for the Twenty-First Century: Using Recent Research on Learning to Enhance Training. Innovations in Education and Teaching International, 39(4), 265-270. https://doi.org/10.1080/13558000210161115

Ferrero, M., Garaizar, P., \& Vadillo, M. A. (2016). Neuromyths in Education: Prevalence among Spanish Teachers and an Exploration of Cross-Cultural Variation. The Journal of Frontiers Human Neuroscience. https://doi.org/10.3389/fnhum.2016.00496

Gleichgerrcht, Z., Luttges, B. L., Salvarezza, F., \& Campos, A. L. (2015). Educational Neuromyths among Teachers in Latin America. Mind, Brain, and Education, 9(3), 170-178. https://doi.org/10.1111/mbe.12086

Goswami, U. (2004). Neuroscience and education. British Journal of Educational Psychology, 74, 1-14. https://doi.org/10.1348/000709904322848798

Goswami, U. (2006). Neuroscience and education: From research to practice? Nature Reviews Neuroscience, 7 , 406-413. https://doi.org/10.1038/nrn1907

Gülpınar, M. A. (2005). Beyin/Zihin temelli öğrenme ilkeleri ve eğitimde yapılandırmacı modeller. Kuram ve Uygulamada Eğitim Bilimleri Dergisi, 5(2), 271-306.

Haladyna, T. M., \& Rodriguez, M. C. (2013). Developing and validating test items. New York, NY: Routledge.

Howard-Jones, P. A. (2014). Neuroscience and education: Myths and messages. Nature Reviews Neuroscience, 15, 817-824. https://doi.org/10.1038/nrn3817

Jensen, E. (1998). Teaching with the brain in mind. Alexandria: ASCD (Association for Supervision and Curriculum Development).

Karakus, O., Howard-Jones, P. A., \& Jay, T. (2014). Primary and Secondary School Teachers' Knowledge and Misconceptions about the Brain in Turkey. International Conference on New Horizons in Education, Paris, France, Procedia-Social and Behavioral Sciences.

Karasar, N. (2013). Bilimsel araştırma yöntemi. Ankara: Nobel Yayın Dağıtım.

Lethaby, C., \& Harries, P. (2016). Learning styles and teacher training: Are we perpetuating neuromyths? ELT Journal, 70(1), 16-27. https://doi.org/10.1093/elt/ccv051

Organisation for Economic Co-operation, and Development [OECD]. (2002). Understanding the Brain: Towards a New Learning Science. Paris.

Organization for Economic Co-operation, and Development [OECD]. (2007). Understanding the Brain: Birth of a New Learning Science. Paris: Organization for Economic Co-operation and Development. 
Pasquinelli, E. (2012). Neuromyths: Why do they exist and persist? Mind, Brain, and Education, 6(2), 89-96. https://doi.org/10.1111/j.1751-228X.2012.01141.X

Rato, J. R., Castro-Caldas, A., \& Abreu, A. M. (2013). Neuromyths in education: What is fact and what is fiction for Portuguese teachers? Educational Research, 55(4), 441-453. https://doi.org/10.1080/00131881.2013.844947

Sousa, D. A. (2001). How the brain learns: A classroom teacher's guide. California: Corwin Press.

Sylwester, R. (1995). A Celebration of neurons: An educator's guide to the human brain. Alexandra: Association For School Supervision and Curriculum Development.

Tokuhama-Espinosa, T. (2010). Mind, Brain, and Education Science: The New Brain-Based Learning. New York, NY: W.W: Norton.

Wolfe, P. (2001). Brain matters: Translating research into classroom practice (2nd ed.). Virginia: Association for Supervision and Curriculum Development.

\section{Copyrights}

Copyright for this article is retained by the author(s), with first publication rights granted to the journal.

This is an open-access article distributed under the terms and conditions of the Creative Commons Attribution license (http://creativecommons.org/licenses/by/4.0/). 